\title{
The heterogeneity of internationalisation in knowledge intensive business services
}

\begin{abstract}
The general process of internationalisation of knowledge intensive business services (KIBS) is widely recognised, but knowledge of the forms, motivations and spatial patterns of this type of internationalisation remains limited. This article addresses this gap by comparing the sectors of legal services and engineering consulting, which differ in their specific service characteristics. Based on an analysis of the office networks of international firms, we attempt to identify typical patterns of international expansion and examine the heterogeneity among the firms in both sectors. We reveal that the specific service characteristics, especially in terms of knowledge and client relationship, influence significantly the spatial outcome of international expansion. Also the country of origin with its particular institutional environment may affect the opportunities of, and targets for, expansion.
\end{abstract}

Keywords: knowledge intensive business services, multinational corporations, international office locations, cluster analysis

\section{Introduction}

The internationalisation of industrial production and the growth of trade have been the most important elements of globalisation over the last decades. A relatively new phenomenon and element of globalisation is the internationalisation of services. For a long time, services were mainly oriented towards national markets, a fact which was strongly influenced by the characteristics of services - immateriality, interaction processes, uno-actu-principle - and by barriers to entry in existing markets in foreign countries. With the General Agreement of Trade in Services (GATS) of the World Trade Organization (WTO), internationalisation of services has been facilitated since 1995 . In addition, the development of global productionand market-systems as well as the privatisation of public services created international expansion opportunities for service enterprises. Transportation and logistics, tourism and retailing were the early sites of service internationalisation. Today, however, internationalisation can be found in most subsectors of services. In recent times the service sector has contributed more than $50 \%$ to international foreign direct investment worldwide.
Throughout the globalisation processes of the last decades, the conditions for international expansion of services have changed hugely. Service enterprises now have to fulfil more functions in a globalised world and they can exploit new international expansion opportunities. The number of actors present in international activities is increasing and a specialisation of activities can be observed (see the discussion of "global commodity chains" and "global production networks"; COE/DICKEN/ HESS 2008; HENDERSON et al. 2002); within these global production- and consumption-systems new conditions for services activities develop:

- Due to the global organisation of production and consumption, service enterprises have to provide new functions in transport and logistics, in consultancy, in advertising/ marketing or in finance (see NUHN 2007; SEDLACEK 2003; JONES 2005; FAULCONBRIDGE 2006).

- With the increasing importance of knowledge, innovations and knowledge management, services have to fulfil new complex 
requirements. Research/development, consultancy, and marketing/advertising are becoming the factors most integral to success in the global market. Service enterprises not only provide these services for other enterprises, they also generate innovations themselves (STRAMBACH 2008).

- The liberalisation of service activities on the national level, which were previously tightly regulated, and the better conditions for international service transfer (GATS) are creating new opportunities for international expansion in almost all service subsectors (see HaAs/ Neumair 2006; StAHLECKER et al. 2006).

Studies on the internationalisation of services, and especially of KIBS, are a relatively new area of scientific research. In addition to their knowledge intensity, KIBS differ from other services in the high degree of immateriality and customisation of the service to the clients' demands. Selling the expert knowledge of the employees is usually organised in temporary projects and involves frequent interactions between client and service provider (LøWENDAHL 2005). These special characteristics influence the way KIBS internationalise. With the activities of KIBS becoming ever more global in recent decades (WINCH 2008), there has been an increase in research on their internationalisation. The following major topics in these studies are of relevance to our approach: Motivations, limitations and the spatial patterns of the internationalisation process.

- It seems that in addition to the traditional explanations of cost advantages and market seeking strategies, the motivation of KIBS to internationalise is especially influenced by their networks (BRYSON/DANIELS/WARF 2007; GLÜCKLER 2006; JONES 2005). These networks of clients and partner firms are primarily important because of the need for direct contacts to clients for KIBS and the crucial role of trust in providing immaterial products. KIBS are providing very specific services and individual solutions that can only be developed during the direct interaction process between provider and user.

- Further, internationalisation could be limited or at least hampered by differences in language, culture, and institutional regulations or absent market knowledge and reputation.
This psychic distance (e.g. JOHANSON/VAHLNE 1977) as well as spatial distance could be overcome by "experimental learning" (MoSCHETT 2007; e.g. retailing: KULKE 2011) or making use of the above mentioned networks (GLÜCKLER 2006).

- Following these arguments, spatial patterns evolve as a result of complex interactions between network embeddedness and distance factors. Previous studies also suggest that the market choices of KIBS might be more influenced by market potentials and the structure of their networks than by distance to foreign markets (COVIELLO/MARTIN 1999).

- Additionally, the societal embeddedness of firms in institutional frameworks of their home countries (e.g. cultural, political background) might influence "their economic behaviour at home as well as abroad" (Hess 2004, 176).

- Therefore, it also influences their ability to internationalise and the forms this takes. These "varieties of capitalism" (HALL/ SOSKICE 2001) across different home countries, and the resulting internationalisation patterns of firms, may ultimately be consistent in the longer-term, due to the principle of "path dependency" (STRAMBACH/STORZ 2008).

As stated above, there are different, somewhat contradictory, explanations for the internationalisation of business services. Typically, empirical studies of KIBS focus on one particular sector like legal services, management consulting or advertising. The specificity of these sectors is generally recognized (e.g. JONES 2007; GLÜCKLER/ARMBRÜSTER 2003) and, in turn, a certain degree of heterogeneity among the subsectors of KIBS is also accepted. This heterogeneity has already been analysed by MALHOTRA/MORRIS (2009) in a comparative study of legal, accounting and engineering services, in terms of primary non-spatial factors like differing organisational forms. However, little is known about how these sector-specific characteristics influence internationalisation strategies. At present there are no systematic studies comparing patterns of internationalisation in several subsectors of KIBS - a knowledge gap addressed by this article. We analyse the international office networks of KIBS focusing on the question: How do sector-specific characteris- 
tics influence the internationalisation patterns of knowledge intensive business services?

To answer this question, we consider the heterogeneous characteristics of knowledge intensive business services and the spatial implications resulting from this heterogeneity with reference to the cases of engineering consulting and legal services. We empirically analyse how international office networks differ between the subsectors of services and between the home countries of the companies with their specific institutional and economic conditions. Finally, after discussing the results we outline areas for further research.

\section{Law firms and engineering consultancies}

The engineering consulting and legal services sectors were chosen because they are seen to offer differing characteristics in their geographies of international expansion, location patterns and global organisational forms. Although some aspects of the internationalisation patterns of law firms have already been analysed in case studies (e.g. BEAVERSTOCK 2004; FAULCONBRIDGE et al. 2008), this sector has not been compared to other subsectors. Furthermore, only firms from the USA and The United Kingdom (UK), which have a special position among international law firms, and are not representative for this subsector in general, have been assessed. According to Hess (2004) and Strambach/StORZ (2008), institutional conditions in the home market governmental regulations, centralist or federal administration systems, law systems, economic development and market volumes - influence the internationalisation of companies and therefore their locational patterns. For example, in the case of law firms, the dominance of firms from the USA and the UK in terms of size compared to smaller firms from continental European countries can be traced back to a first-mover advantage, one which was enabled by beneficial institutional settings in the home market. These competitive advantages may have a long term impact on the international legal consulting sector and its heterogeneity, depending on the firms' country of origin. But over the course of time institutional change influenced by economic actors might also lead to more beneficial institutional settings in other countries (STRAMBACH/STORZ 2008, 144 ff.).
Not only the extent and forms of internationalisation, but also the choice of particular countries may vary between firms of the same sector from different countries. In this case, specific characteristics such as cultural and administrative proximity between home and potential target countries could be important (GHEMAWAT 2001; BERRY et al. 2010).

Because of these home country specific features of companies, it is also useful to analyse firms from different countries along this second dimension in order to further highlight the heterogeneity of KIBS. To examine the impact of these factors, we chose companies from France, Germany, the Netherlands and UK which in our view differ in terms of the institutional contexts mentioned above. This selection made should provide an insight into the effects of varying institutional contexts on the development and expansion potentials of KIBS sectors.

The work of law firms is focused on "the interpretation and application of statute or case based law which may or may not be tested in court" (MALHOTRA/MorRis 2009, 902). In this article, we focus on firms whose work is relevant to economic issues, such as antitrust, employment, intellectual property and insolvency law. Further competences include consulting in transactional issues like direct investments and assistance in international contracting (Pöllath/SAENGer 2009, 10). Law firms are typically small and organised in the legal form of a partnership. Only the seven largest law firms in the world have 2,000 to 3,000 lawyers (Law.com: The Global 100, 2010). While these big firms have their headquarters in the USA or the UK, nearly all of the continental European firms consist of less than 1,000 lawyers (The Lawyer: European 100, 2010).

A wide range of technology-based services are offered by engineering consulting firms. Most important subsectors are civil engineering, industrial engineering and environmental engineering (ARANDA 2002, 270). While civil engineering is closely related to the construction industry, industrial engineering services focus on the optimisation of complex activities and systems of their clients (see e.g. BADIRU 2005), and are related to a broad range of industries especially in manufacturing. Typically, the work of consulting engineers is closely related to the client's investment projects, resulting in 
a "value co-creation with the clients" (OJANEN et al. 2008, 151). This includes feasibility studies, technical design, planning, or supervision during the realisation phase (KREITL/OBERNDORFER 2004, 692; OJANEN et al. 2008, 51). The size of consultancies doing international business ranges from 130 to 18,000 employees within the top 300 European consultancies (STD 2009).

\section{Spatial implications \\ of heterogeneous sector characteristics}

As a base for a systematic comparison of the two sectors and the discussion of spatial implications, we draw particularly upon the work of MALHOTRA/MorRIS (2009). Based on insights from the sociology of professions, they compare legal, accounting and engineering services according to their characteristics in terms of "nature of knowledge", "jurisdictional control" and "relations with clients". While their work is mostly focused on the different organisational forms of these branches which emerge, their theoretical arguments also entail several spatial consequences.

The knowledge required for the work of law firms is of a normative epistemological nature, which means that it describes values or "what ought to be the case". This knowledge is established either through governmental statute or precedents, which are in turn based on jurisprudence and social contracts (HALLIDAY 1985, 424; Malhotra/Morris 2009, 899 ff.) and vary between legislations and countries. Beside the contents of law, the procedures of jurisprudence, interpretation and application of law also depend on the particular legal system (BEAVERSTOCK et al. 1999, 453; FAULCONBRIDGE et al. 2008). Since lawyers are educated and regulated by national associations, their knowledge is usually focused on the national contexts of one particular country, and they need special admissions to work in other legislative systems. However, the nature of legal advice is becoming increasingly international. Standards based on American and British common law are beginning to be established in international contract law, advice on mergers and acquisitions and finance related law. Despite this trend other international services in the fields of taxation, real estate and employment are still regulated solely by national legislations.

In contrast, the knowledge base of engineering consultancies is of a technical nature and is gained via empirical methods such as observation and experimental inquiry. Engineers are concerned with matters of fact (HALLIDAY 1985, 424; MalHotra/Morris 2009, 899), which means that the required technical principles are universal and applicable in every country or geographic jurisdiction. Country specific contexts are especially important with regard to government regulations or "different social and physical environments" (MALHOTRA/MORRIS 2009, 904 ff.). Recent geographic discussions of innovation processes view engineering based knowledge as a prototype for a "synthetic" knowledge base (ASHEIM/EBERSBERGER/ HeRstAD 2010; MATTES 2012). This refers to integrative knowledge creation through the development of functional solutions by designing or constructing something (knowhow). This process is not only context specific with regard to the aforementioned social and physical environments but also because it takes place in local communities of practice. Due to the important role of tacit knowledge and faceto-face interaction the transfer of engineering knowledge in learning processes is regarded as highly distance sensitive (ASHEIM/EBERSBERGER/HERSTAD 2010, 6 ff.). Thus, unsurprisingly, we can identify factors which hinder the transfer of knowledge and the application of existing knowledge in foreign contexts in both sectors. However, what separates them is that engineering services are additionally based on more universally valid knowledge. The skills of an engineer also encompass the application of principles derived from natural sciences. Relating to the discussion of knowledge bases this refers to an analytical knowledge base which is far less distance sensitive (loc. cit. 9). In simple terms: The principles of structural analysis are valid in each geographic context, legal texts are not.

Thus the differences in the nature of knowledge in each sector result in differences in the permeability of national boundaries for engineering consulting and law firms. It is most probable that this dissimilarity influences spatial patterns and strategies of internationalisation. We can assume that engineering consultancies are generally more involved in international business than law firms. Such a view is supported by the generally high level of jurisdictional control within the law sector. Not only are other professions prohibited from offering legal services but normally lawyers from other countries are as well. Furthermore, if we 
take a look at the deep embeddedness of the normative knowledge of law firms in institutional contexts, we should expect a stronger bias amongst law firms towards countries of the European Union (EU).

Another characteristic of professional service firms which differs is the nature of the client relationship. MALHOTRA/Morris (2009, 914 f.) claim that engineering consulting firms are habitually involved in consultancy projects that require a high frequency of co-presence in particular phases, especially in the "supervision and management of construction. As such spatial proximity to the clients is beneficial if not necessary. In contrast, the contact between lawyers and customers is less frequent because lawyers can perform most of their work separate from the client. For this reason, and the generally lower distance sensibility of highly specialized services like law consulting (GLÜCKLER 2004,72 f.), it could be expected that spatial proximity to clients is less important for law firms than for engineering consulting firms, and that this might result in a smaller number of offices per national market.

If a firm decides to establish just one or only a few subsidiaries in a particular country, cities of high centrality (or even global cities, according to BEAVERSTOCK/SMITH/TAYLOR 1999) seem to have important advantages, such as access to a labour market with qualified personnel for recruitment (GLÜCKLER 2004, 75) and good connections to international transportation facilities. Being present in economic and financial centres facilitates access to clients and the maintenance of face-to-face contacts which are important for trust-building (JONES 2007, 233 ff.). Further, cities with high-ranking administrative functions allow for access to governmental institutions. These factors are particularly important to law firms (BEAVERSTOCK et al. 1999, 454). Furthermore, for both sectors spatial proximity to other service firms can encourage the establishment of clusters which provide opportunities for cooperation, common learning processes and the exchange of tacit knowledge (BATHELT et al. 200432 ff.; FAULCONBRIDGE 2007, 15 ff.). But overall, the work of engineering consulting firms at non-central construction sites and the locations of manufacturing industries should result in the decision to site several offices in non-central locations. So we expect that the differing spatial organisation of the clients will also have a major impact on the locational choices of KIBS firms.

This brief discussion has shown that despite certain common characteristics, from a geographical perspective, knowledge intensive business services should not be viewed as homogenous category. Instead, we argue that differences in the nature of knowledge and types of client relationship influence the spatial outcome of internationalisation processes. This is true for the scope of internationalisation as well as the destination of international activity. This influence will be examined in the following comparative analyses of international office networks of the legal services and engineering consulting sectors.

\section{Definition of sample and data collection}

To examine the issues raised above, we gathered data on the international office networks of firms from the two sectors. Because information on these networks is not available through current official or commercial data sources, we conducted internet-based research. Firms included in this research had to match the following criteria:

- The firm's core activity was in either the legal or engineering consulting services.

- The firm's headquarter was located in the UK, France, the Netherlands or Germany.

- The firm had at least one permanent international office.

Furthermore, to select comparable samples for each sector we included the size of the firm as an additional criterion. The included engineering companies were chosen from the European top 300 consulting engineering and architectural groups in 2009 (STD 2009). The law firms were selected from the following sources: lists of the 100 largest UK and the 100 largest continental European law firms in 2009 (The Lawyer 2009), Deutsche Kanzleien 1-70 (JUVE 2011), Chambers \& Partners, and HG Legal Directories.

Finally, we identified 90 engineering firms, based in the UK (31), Germany (25), France (17) and the Netherlands (17), and 78 law firms, 25 from the UK, 20 from Germany, 19 from France and 14 from the Netherlands. In the last quarter of 2010, we collected data on the locations of current international offices for 
all 168 firms. Temporary project offices, common in the consulting engineering sector (FENton/Pettigrew 2000; Malhotra/Morris 2009), were not included. If available we also noted the year the office was established and if this resulted from a greenfield investment, an acquisition or setting up a joint-venture. The data was gathered from various company and subsidiary websites, companies' press releases and annual company reports. In some cases data was supplemented by enquiries to the respective company, or was taken from articles in specialist journals. We also noted if the office location was of high centrality in its national context. We defined location of high centrality as cities matching at least one of the following criteria: i) size: one of the three largest national cities according to population size; ii) administrative centrality: capital city; iii) national hub: largest national airport (according to passenger volume) or container port.

\section{Empirical results}

\section{International office locations and country of origin}

The gathered data allows for the exploration of the research issue through multiple approaches. The starting point of our study is a descriptive analysis of the office locations of the two sectors with a special focus on the country of origin. Thus, in this following section we address the question: Which differences in locations of international offices become obvious between firms when the sector and country of origin is considered?

First, with regard to legal consultancies, the exceptional position of UK firms is clear. On average they have more employees and larger office networks with more developed national markets than the firms of France, Germany and the Netherlands. From this it follows that there are few countries where French, German and Dutch firms are present in greater numbers than UK consultancies (see Tab. 1). The dominance of UK, and also US-American law firms, in global legal services has been broadly discussed in specialist articles with regard to their distinct institutional contexts. As MORGAN/QUACK $(2005,1767)$ referring to OsIEL $(1990,2032 \mathrm{ff}$.) argue, historically British lawyers were quicker to adopt an entrepreneurial approach, giving commercial clients economic-related advice. Lawyers in civil law states like Germany and
France were subject to stronger regulation by their governments and this has inhibited such entrepreneurial activity. German lawyers were generally employed as experts in the law departments of companies, (Morgan/QUACK 2005, 1767 f.), while in France ethical guidelines prohibited business contacts during the $19^{\text {th }}$ century (OsIEL 1990, 2042). The comparatively early abandonment of size restrictions for British partnerships in 1967 allowed further expansion in both size and international activities (FAULCONBRIDGE 2008, 505), while the fact that international transactions are usually concluded on the basis of New York State or British law gives Anglo-American law firms a clear advantage in conducting this kind of transaction globally (FAUlCONBRIDGE et al. 2008; PöLlath/SAENGER $2009,15)$. These are the main expansion-related advantages enjoyed by UK law firms compared to consultancies from the other countries.

Concerning the most favoured target countries of law firms, the dominance of Belgium is evident. This may be traced to the importance of Brussels as the location of the main institutions of the EU, which are central to the legal sector due to the increasing amount of legal regulations emerging from the supranational level. However, differences between the countries of origin are noticeable. The colonial link seems to be most important to firms of French origin, which prefer to invest in the former African colonies of Morocco and Algeria, where the law systems is part of the French legal family (Emory Law 2012) and has been shaped by the former colonizer. The fact that French is still an important commercial language in these countries further facilitates business for French consultancies. It could be suggested that there is a similar relationship between British consultancies and former colonies like Hong Kong, Singapore, the USA and in part Australia. It is not, however, clear whether administrative and legal similarities remaining from the colonial past or the commercial importance of these places or - more likely - a mixture of the two, are the key reason for investment in these locations. Given that firms from other countries are also present in these locations, it is impossible to measure the exact importance of factors such as ease of adaptation to local contexts due to common law legislative systems for British firms. In contrast, Dutch firms favour the neighbouring Benelux countries - which share similar law systems and administrative contexts - and Germany over former overseas 
Tab.1: Permanent country presences of leading European law firms*

\begin{tabular}{|c|c|c|c|}
\hline $\begin{array}{l}\text { German law firms } \\
\text { (20 in total) }\end{array}$ & $\begin{array}{l}\text { French law firms } \\
\text { (19 in total) }\end{array}$ & $\begin{array}{l}\text { British law firms } \\
(25 \text { in total) }\end{array}$ & $\begin{array}{l}\text { Dutch law firms } \\
\text { (14 in total) }\end{array}$ \\
\hline $\begin{array}{l}\text { Belgium (15) } \\
\text { China (5) } \\
\text { UK (5) } \\
\text { Spain (4) }\end{array}$ & $\begin{array}{l}\text { Belgium (10) } \\
\text { Morocco (7) } \\
\text { Algeria (5) } \\
\text { China (4) }\end{array}$ & $\begin{array}{l}\text { Belgium (20) } \\
\text { France (19) } \\
\text { China (18) } \\
\text { Hong Kong (18) } \\
\text { United Arab Emirates } \\
\text { (18) } \\
\text { Singapore (16) } \\
\text { Germany (13) } \\
\text { Russia (13) } \\
\text { Spain (13) } \\
\text { Italy (11) } \\
\text { Japan (10) } \\
\text { Netherlands (9) } \\
\text { Poland (9) } \\
\text { Czech Republic (8) } \\
\text { USA (7) } \\
\text { Hungary (6) } \\
\text { Qatar (6) } \\
\text { Thailand (6) } \\
\text { Slovakia (5) }\end{array}$ & $\begin{array}{l}\text { UK (7) } \\
\text { Belgium (6) } \\
\text { USA (6) } \\
\text { Germany (3) } \\
\text { Luxembourg (3) }\end{array}$ \\
\hline
\end{tabular}

* Countries are only included if at least $20 \%$ of companies are present in country.

Source: own survey

colonies. In general, however, being neighbours does not appear to be an important factor in the expansion of law firms. In addition, the relevance of colonial links for law firms appears most significant for the French and, to a lesser degree, British firms.

Typical destinations for law firms are financial centres and growing economies. Among the latter, China, Russia, the Persian Gulf and Eastern Europe are the most common destinations for direct investments. However, peculiarities, dependent on the countries of origin, do exist. For instance, most of the Dutch firms researched established offices in London and New York City, while the majority of UK consultancies focused on China and the United Arab Emirates, followed by the large Western European economies, Russia and Tokyo. A quarter of the German firms examined expanded into Eastern European countries like Poland, Hungary and Russia, even if there was no single market with more than $20 \%$ of the consultancies. According to MorGan/QUACK $(2005,1775)$, this Eastern expansion of German firms can be explained with reference to their experience of post-socialist privatisation processes, the high importance of Eastern Europe for German direct investments and similarities concerning the post-socialist civil law systems (CIA Factbook 2011).

With regard to engineering consultancies, a dominance of firms from one particular country comparable to that of the UK in the legal consultancies sector could not be identified. In contrast to legal services, engineering companies from all four countries have established extensive office networks and reveal a shared tendency to favour neighbouring countries, especially those with a common language. Austria is only a relevant market for German firms, Ireland for firms from the UK, while the presence of French and Dutch companies in Belgium is well above average, as is that of German and French companies in Switzerland. Furthermore, former colonial links are still mirrored in the more or less exclusive office locations of French (in the Maghreb Countries), British (in the Commonwealth and USA) and also Dutch companies (in Indonesia and Malaysia). These observations are in line with 
Tab.2: Permanent country presences of leading European engineering consulting firms*

\begin{tabular}{|c|c|c|c|}
\hline $\begin{array}{l}\text { German engineering } \\
\text { consultancies } \\
(25 \text { in total) }\end{array}$ & $\begin{array}{l}\text { French engineering } \\
\text { consultancies } \\
\text { (17 in total) }\end{array}$ & $\begin{array}{l}\text { British engineering } \\
\text { consultancies } \\
\text { ( } 31 \text { in total) }\end{array}$ & $\begin{array}{l}\text { Dutch engineering } \\
\text { consultancies } \\
\text { (17 in total) }\end{array}$ \\
\hline $\begin{array}{l}\text { Russia (14) } \\
\text { United Arab Emirates } \\
\text { (9) } \\
\text { Austria (9) } \\
\text { Poland (9) } \\
\text { China (8) } \\
\text { Romania (8) } \\
\text { Czech Republic (7) } \\
\text { Turkey (7) } \\
\text { USA (7) } \\
\text { Bulgaria (6) } \\
\text { Great Britain (6) } \\
\text { Hungary (6) } \\
\text { Italy (6) } \\
\text { Switzerland (5) } \\
\text { Spain (5) } \\
\text { France (5) } \\
\text { India (5) } \\
\text { Slovakia (5) } \\
\text { Vietnam (5) }\end{array}$ & $\begin{array}{l}\text { Spain (11) } \\
\text { Morocco (11) } \\
\text { Belgium (10) } \\
\text { Romania (10) } \\
\text { Germany (9) } \\
\text { Great Britain (9) } \\
\text { Italy (9) } \\
\text { Poland (9) } \\
\text { Switzerland (8) } \\
\text { India (7) } \\
\text { Algeria (6) } \\
\text { Argentina (5) } \\
\text { Brazil (5) } \\
\text { China (5) } \\
\text { USA (5) } \\
\text { United Arab Emirates } \\
\text { (4) } \\
\text { Tunisia (4) } \\
\text { Bulgaria (4) } \\
\text { Czech Republic (4) } \\
\text { Japan (4) } \\
\text { Netherlands (4) } \\
\text { Russia (4) } \\
\text { Sweden (4) }\end{array}$ & $\begin{array}{l}\text { United Arab Emirates } \\
(27) \\
\text { China (17) } \\
\text { India (17) } \\
\text { Ireland (15) } \\
\text { Romania (15) } \\
\text { Australia (15) } \\
\text { Hong Kong (14) } \\
\text { USA (14) } \\
\text { Germany (12) } \\
\text { Poland (12) } \\
\text { Qatar (10) } \\
\text { Russia (10) } \\
\text { Singapore (10) } \\
\text { Canada (9) } \\
\text { France (9) } \\
\text { Spain (8) } \\
\text { Italy (8) } \\
\text { Netherlands (8) } \\
\text { South Africa (8) } \\
\text { Libya (6) } \\
\text { Oman (6) } \\
\text { Vietnam (6) }\end{array}$ & $\begin{array}{l}\text { Belgium (12) } \\
\text { Germany (11) } \\
\text { USA (9) } \\
\text { United Arab Emirates } \\
\text { (8) } \\
\text { France (8) } \\
\text { Great Britain (7) } \\
\text { India (7) } \\
\text { China (6) } \\
\text { Spain (6) } \\
\text { Russia (6) } \\
\text { Czech Republic (5) } \\
\text { Poland (5) } \\
\text { Saudi Arabia (5) } \\
\text { Vietnam (5) } \\
\text { Indonesia (4) } \\
\text { Malaysia (4) } \\
\text { Oman (4) } \\
\text { Romania (4) }\end{array}$ \\
\hline
\end{tabular}

* Countries are only included if at least $20 \%$ of companies are present in country.

Source: own survey

considerations and empirical studies about multi-dimensional, cross-national distance and the positive influence of proximity on international trade and foreign direct investment (e.g. GHemaWAT 2001; BerRy et al. 2010; BeugelsDIJK/FRIJNS 2010).

Alongside these observations, it was apparent that Brazil, Russia, India, and China (so called BRIC-countries), Eastern Europe and the Persian Gulf are the favoured investment destinations for the companies examined. This holds true regardless of home country. What differs, however, is the relative importance of these regions. While German firms focus on Eastern Europe and especially Russia, the favoured destinations of British consultancies are mainly outside Europe, with an extremely high presence in the Gulf Region (United Arab Emirates, Qatar and Oman). The international office locations of Dutch companies do not show such a noticeable concentration. Apart from the Maghreb Countries French consultancies tend to favour European countries as destinations for permanent offices. Generally engineering consulting firms from all four countries successfully export their technical knowledge throughout the world.

\section{Cluster analysis: Exploring the complex} spatiality of office networks

The previous descriptive analyses have revealed some fundamental differences between the international geographies of legal and engineering services. In particular, the results of research on the law firms, with the dominant UK firms, indicate heterogeneity within the sector. It is also possible that the office networks of firms display similar spatial patterns despite belonging to different sectors. In the following we examine these issues by searching for distinct types of international office networks and 
Tab.3: Cluster statistics: mean values and cluster assignment

Indicators mean values per type of office network

\begin{tabular}{lccccc}
\hline & $\begin{array}{c}\text { Globally- } \\
\text { spanning }\end{array}$ & $\begin{array}{c}\text { International } \\
\text { "next door" }\end{array}$ & $\begin{array}{c}\text { Second- } \\
\text { tier-cities }\end{array}$ & $\begin{array}{c}\text { First-tier- } \\
\text { cities }\end{array}$ & $\begin{array}{c}\text { Mono- } \\
\text { regional }\end{array}$ \\
\hline $\begin{array}{l}\text { Number of countries with } \\
\text { established international office }\end{array}$ & 29,3 & 13,0 & 6,5 & 7,8 & 1,6 \\
$\begin{array}{l}\text { Number of international offices } \\
\text { per country }\end{array}$ & 2,0 & 4,8 & 1,6 & 1,3 & 1,1 \\
$\begin{array}{l}\text { Share of offices located in cities } \\
\text { of high centrality }\end{array}$ & $67 \%$ & $30 \%$ & $47 \%$ & $93 \%$ & $97 \%$ \\
$\begin{array}{l}\text { Macro-regional concentration } \\
\text { of international offices }\end{array}$ & 0,17 & 0,33 & 0,38 & 0,32 & 0,99 \\
\hline & Number of companies per cluster, sector and country of origin \\
\hline Germany & - & - & 3 & 10 & 7 \\
France & - & - & - & 7 & 12 \\
LK & 2 & - & - & 21 & 2 \\
Netherlands & - & - & - & 7 & 5 \\
\hline Germany & 3 & - & 10 & 9 & 3 \\
France & 5 & 3 & 6 & 3 & - \\
Engineering & 9 & 3 & 5 & 12 & 2 \\
\hline
\end{tabular}

Source: own survey

answering the question: What are typical patterns of international office networks of KIBS?

To reveal the complex structures of such networks, we rely on more sophisticated methods of multivariate statistics appropriate to this case: a hierarchical cluster analysis. ${ }^{1}$ This multivariate method allows for a complex analysis of collected data with the goal of building homogenous groups (clusters). From this it is possible to identify typical patterns of office networks and to assign firms to their appropriate pattern. As similarity within clusters and dissimilarity between clusters are the two key criteria underlying the clustering process, the results of the cluster analysis provide an appropriate means of assessing the gathered data in terms of our research question. We base the identification of typical patterns on the following indicators:

The number of countries in which a firm main- tains international offices (1) is the first indicator and represents the scope of the company's office network. The number of international offices per country (2) and the share of offices located in cities of high centrality (3) reflect the spatial organisation within national foreign markets. The fourth variable, spatial concentration (4), addresses the eventual focus of a company's international offices on selected geographic (world-) regions. To measure this concentration we calculated the Herfindahl-Index for the distribution of offices across these (world-) regions. The higher the value the higher the spatial concentration of international offices is; the lower the value the more the offices are dispersed across the globe. Therefore, this variable is an additional indicator of the global character of the firm's international office network. The regions we used to calculate the variable correspond to those delineated by the United Nations Statistics Division (2010) (see Fig. 1 and 2). 
Through the cluster analysis, we can identify five types of international office networks which differ from each other in terms of scope and structure. We discuss these types in the following sections.

\section{Types of international office networks in} knowledge intensive business services

The globally-spanning office network: This type of firm is the most global one. A large number of subsidiaries and offices build a globally-spanning internal network. An average company of this type has established permanent presences in around 30 countries on several continents. Further, two sub-types may be identified: the multidisciplinary allrounder and the global specialist. The allrounders offer a wide range of services and typically grow through hybrid strategies combining organic growth and acquisitions. In part, this leads to complex organisational structures with a multiplicity of divisions and subsidiary companies organised by geographical market or type of service (see also Fenton/PetTigrew 2000). Some of the largest engineering consultancies in the world belong to this group (eight of the European top 15). In contrast, the global spe- cialist is far less diversified, smaller in size and consequently often less complex in organisational structure.

The globally-spanning office network is more typical for engineering consultancies. The only two law consultancies assigned to this type are the fourth and fifth largest law firms in Europe according to annual turnover (The Lawyer 2010) and are headquartered in the UK. But in general, this kind of office network is untypical for the law sector.

The international firm "next-door": This second type of international office network is also characterized by an extensive international presence. However, it is the only type that combines this presence with deep penetration of national markets via high numbers of offices per country. Thus, despite their global reach, firms tend to maintain an office "next-door" to clients in their developed markets. However, similar extensive office networks in each country are not typical. Rather, extensive national office networks in some countries and single locations in others (usually in cities of high centrality) exist side by side. Extensive office

Fig. 1: International presence of analysed KIBS by type of office network

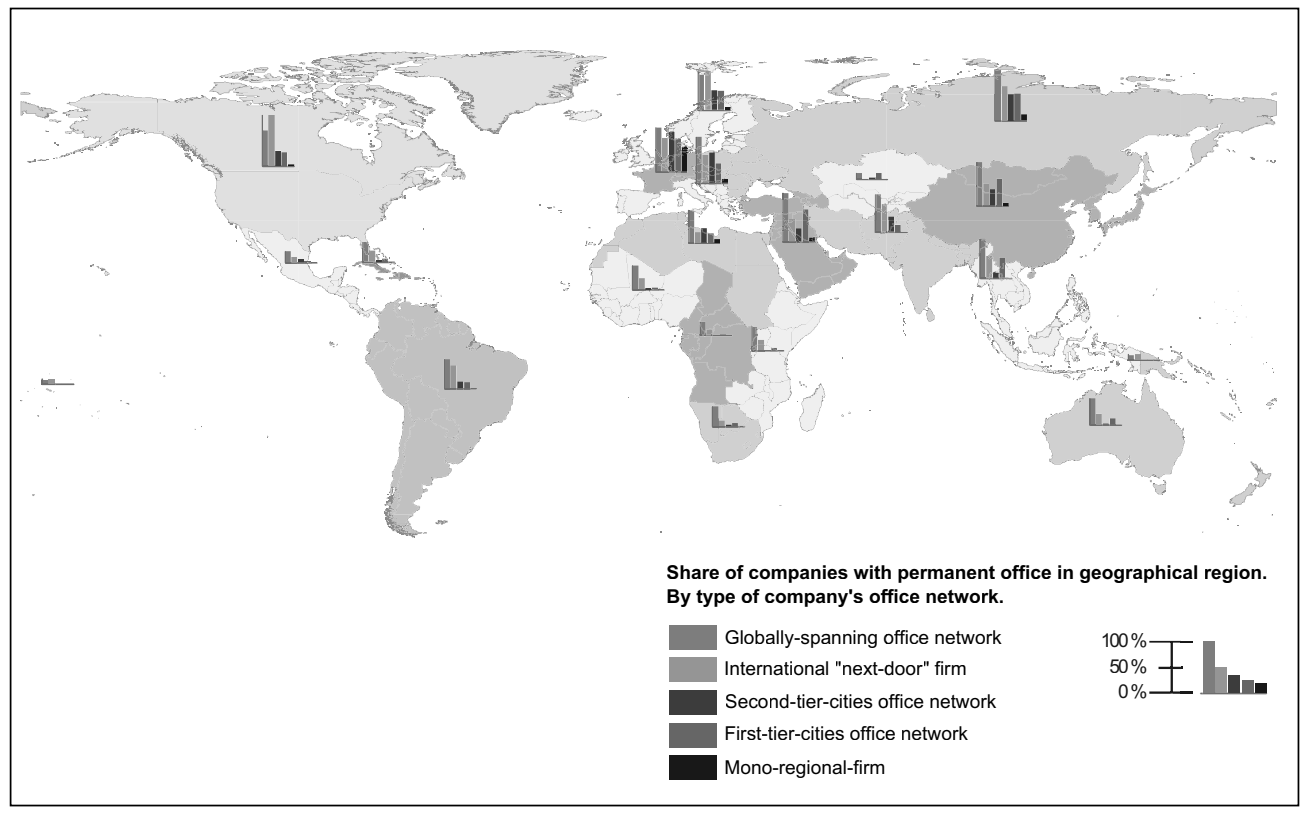

Source: own survey 
networks are especially common in large-area countries (e.g. USA, Canada and Australia) and large economic markets (e.g. Germany, France, UK). They often result from the acquisition of former nation-wide operating domestic consultancies.

From our sample, only engineering consulting firms can be assigned to this type of office network. The above average presence of companies offering industrial engineering services is noticeable. Considering their already discussed close working relationship and co-location with manufacturing firms, assignment to this type of international office networks seems to mirror the location patterns of major client industries. Thus the industrial engineering service firms mirror manufacturing industries in that they are not only concentrated in national centres (e.g. KUJATH/STEIN 2009).

Companies in this cluster are present in nearly all world regions. Above average presence can be observed in North America, South America, Northern Europe and Southern Asia. This reflects the distribution of important markets for the two engineering subsectors dominating this type: industrial engineering, focusing on $\mathrm{Eu}-$ rope and North America; and environmental services, which also have offices in South America, Asia, and some African countries.

The second-tier-cities office network: A typical company of this type tends to establish its international offices in cities of low and medium centrality, even if no extensive office network in the country exists. Beside national centres, economically vital but smaller European cities of the second tier are typical office locations.

The majority of companies assigned to this type belong to the engineering consulting sector, mostly specialised in offering industrial engineering services. Due to the close relation of the clusters' companies to the manufacturing sector this again corresponds with less central office locations observed. However, contrary to the deep market penetration of the "next-door" firm, single national offices dominate. The strong European bias of office locations apparently also holds true for the non-industrial engineering firms of this type. As many regions in Europe are densely populated and economic activity is not only concentrated in a few cities and regions, even locations beyond the economic centres seem to be attractive to structural and environmental engineering services as destinations for their international branch offices.

Three law firms have been allocated to this cluster, but these cases should be seen as exceptions rather than indicators of a preference for less central locations. In all cases one out of three foreign offices is located in a non-central city like Strasbourg in France and Alicante in Spain, home to the Office for Harmonization in the Internal Market of the EU.

The first-tier-cities office network: These office networks almost exclusively include locations of the highest centrality in first-tier-cities. Furthermore, in the main, only one office is opened in each country. Over half of all the law firms of the sample belong to this type, making it the typical office network for organizing transnational legal services, However, the differing number of accessed countries also suggests differing internationalization strategies and a varying ability to open up foreign markets for law firms, depending on the institutional contexts in their home countries.

The engineering consultancies assigned to this type are predominantly multidisciplinary service providing companies with a focus on civil engineering. Due to the characteristics of construction projects, like architectural firms they do not necessarily follow the locations of their clients because it is "unlikely that the firm will have another project in the same city in the immediate future" (FAULCONBRIDGE 2009, 2450). As already discussed above, in these cases temporary project offices are a typical organisational solution to secure a high frequency of face-to-face contact with clients. However, the permanent international offices in firsttier-cities apparently facilitate the management and, more particularly, the acquisition of temporary projects abroad. The presence of engineering consulting firms outside Europe is well above average.

In contrast to engineering consultancies, twice as many law firms established offices in Western European countries. In general, the high presence of law firms in European regions is obvious; however expansion is not limited to this continent. Other frequent target destinations are global financial centres such as New York City, Dubai, Singapore and Hong Kong, where especially legal advice for financial affairs and transactions between corporations 
Fig. 2: International presence of companies assigned to 'first-tier-cities networks'

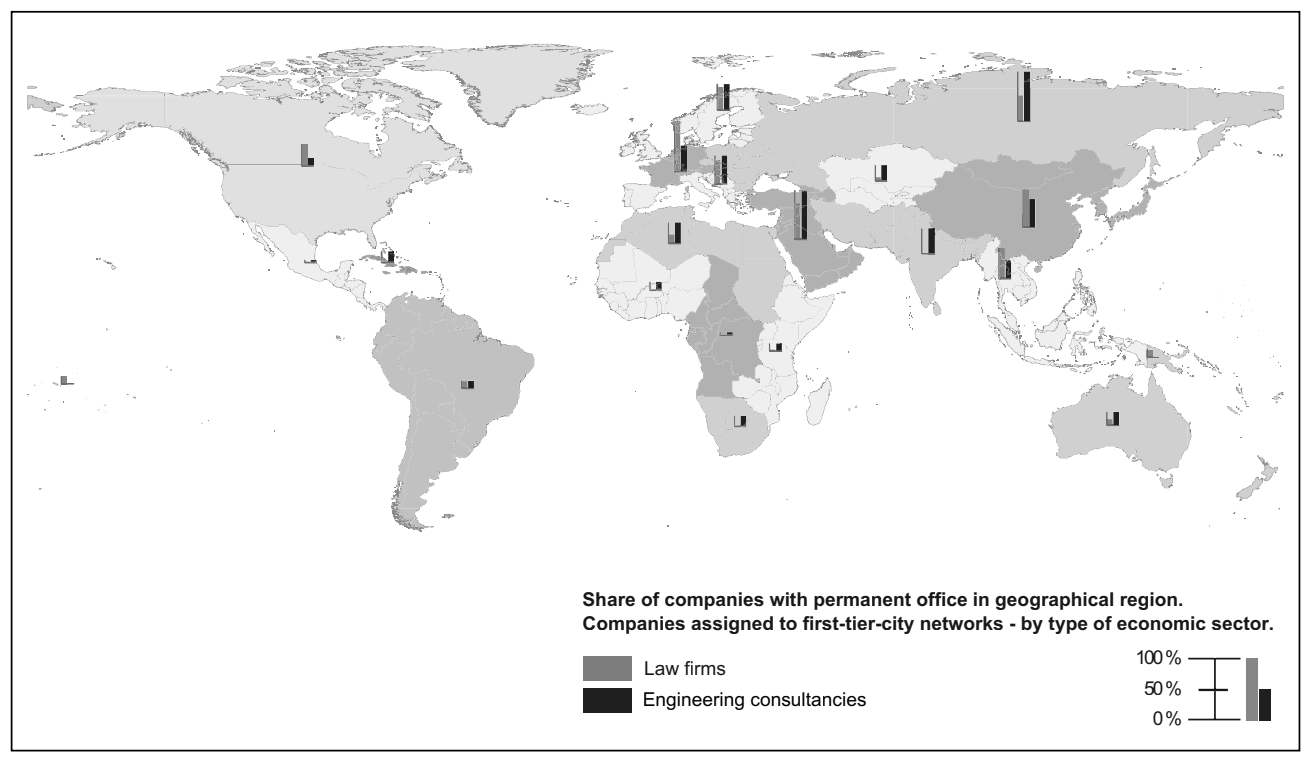

Source: own survey

(e.g. joint ventures, mergers and acquisitions) is in demand (BEAVERSTOCK 2004, 171). In addition, growing markets like China, Eastern Europe and some Middle Eastern states like Qatar and Saudi Arabia are frequently targeted by law firms. However, other emerging nations which are important to the engineering sector like India, Malaysia or Indonesia remain untapped due to the more stringent regulations of the law sectors found there (FAULCONBRIDGE et al. 2008).

The mono-regional-firm: The mono-regionalfirm maintains offices in only one region, with often only one foreign office in a central location of a single foreign country. Apart from the odd exception, only law firms are assigned to this type. Their limited internationalisation could be the result of a number of factors. For law consultancies the permeability of national borders is relatively low due to high national regulation in this sector. Further, companies of this type tend to be small, which inhibits wideranging internationalization. However, the simplest possible explanation for limited office networks is that a firm only recently embarked on internationalisation.

Half of these law firms maintain an office in
Brussels and in most of the cases it is their only one. This singular location pattern can be explained by the significance of Brussels as the principal site of European institutions, nongovernmental organisations, and company headquarters.

One reason why only a few engineering companies are assigned to this type might be that our sample only includes firms from the 300 largest European engineering companies. Although a large share of these companies are only medium sized and many of them do not maintain one single international office, some smaller firms with minor international presence are below the threshold of our sample.

\section{Discussion}

In the sections above we characterised the different types of international office networks identified via cluster analysis. Below, we connect these observations to the prior theoretical discussion concerning spatial differences between legal and engineering services.

A diverse picture of spatial distribution The described types of clusters generally indi- 
cate specific logics in the international spread of knowledge-intensive business-service (KIBS) firms. The opening-up of markets in foreign countries and the interaction process between provider and client seems to be of crucial importance, regardless of communication via electronic media. This is particularly true of the network of global players which have on average developed subsidiaries in 30 countries, encompassing nearly all continents. If we look beyond the large globally operating companies, smaller firms are also present in foreign countries. However, they tend to focus on Europe and selected global macro regions. In comparing legal and engineering services, the following remarks can be made:

(1) Law firms are generally present in fewer countries than engineering consulting firms: There are large differences between the two sectors. While the majority of law firms were assigned to types whose firms generally establish permanent offices in fewer countries, only two are present in the cluster of globally-spanning firms. Furthermore, only a few engineering consulting firms were assigned to the mono-regional-firm category. Obviously, there are variations in the degree to which companies in both sectors are able to skip national borders and take the risk of expansion in foreign markets.

(2) European law firms generally open up more national markets within the EU than engineering consulting firms: The results of cluster analysis reveal that even if office networks from both sectors have similar characteristics, they differ with regard to geographical orientation. In the engineering consulting sector, we observe strategies which are more global, including the establishment of offices in macroregions and countries, while law firms focus largely on Western Europe. Law firms have a particularly small presence in less developed world regions.

(3) Engineering consulting firms possess a larger number of more widely dispersed subsidiaries in a country than law firms: Finally, most law firms only maintain one (or, more rarely, a few) offices at a central place in each foreign country, as nearly all belong to the types of first-tier-cities-networks and mono-regional firm. On the contrary, a higher proportion of engineering firms follow a strategy of having several office sites in foreign countries.
Beyond these descriptive results, the cluster analysis provides information on the underlying relations which affect the spatial behaviour of firms. By distinguishing service sectors according to the characteristics of "nature of knowledge", "cultural and regulatory conditions" and "client-relationship", we are able to provide some explanations for the cluster typology concerning differences in the spatial distribution of the two sectors.

\section{Influence of the nature of knowledge}

The results of the cluster analysis seem to suggest that the differentiation of the location system can be traced back to the influence of the nature of the knowledge utilised by firms. Despite the context specificity of individual technical solutions, the underlying technological knowledge of the engineering firms can be transferred more easily to different cultures and countries because, by-and-large, its principles are universally applicable. The normative knowledge of the law firms on the other hand is predominantly bound to national legal cultures and integrated into national law practices with the consequence that - regardless of the Europeanisation of law and the selective introduction of international economic law - this knowledge cannot simply be transferred to other contexts.

The top engineering consulting firms are therefore mainly found in the cluster of globally spanning firms. In contrast, only a small percentage of law firms have grown into the role of global players. However, there are indications that as a result of economic globalisation, the increasing internationalisation of law (e.g. international contract law) is occurring and the demand for service providers of this type of knowledge in the near future will increase sharply. At the moment, there are only a few companies able to offer a "global system of seamless services" (FAULCONBRIDGE/MUZIO $2011,143)$. The majority of international law firms prefer the EU countries and their shared organizational and cognitive culture as well as other countries to which they are connected through cognitive proximity. Obviously, as the national legal systems of EU countries are gradually intertwined, the action field of law firms will be extended from the national legal framework within the European context. It is also clear that, in comparison to companies from other European countries, for British firms it is easier to assert themselves in global 
markets. This is partly due to the global spread of the Anglo-American legal system as a base for international transactions.

\section{Influence of cultural and regulatory conditions} Clearly, cultural and institutional proximity are also important. The sticking effect of national institutions and cultural behaviours limits in particular the internationalization options of legal firms, because their normative knowledge base is closely connected with the institutional and cultural conditions of their home country. This dual proximity to the home country not only explains the limited international scope of many legal firms but also the leading position of UK legal firms. British companies cannot simply rely on the global spread of the AngloAmerican legal knowledge system, however this provides much of an advantage. Another reason they are able to operate in these markets is because of the early commercialisation of legal services in their home country. Restrictions limiting entrepreneurial activity were removed as early as the 1960s. The simultaneous removal of size restrictions allowed British firms the opportunity to expand activities internationally at an earlier stage than firms from the European continent. Thus British law firms were able to achieve dominance in the global context. The cluster analysis also shows that regulatory and institutional barriers in the target countries hinder access to these countries. Many companies wishing to penetrate growing emerging markets establish offices in China, but not in countries with strong institutional regulation, such as India, Malaysia and Indonesia.

Engineering service providers are also forced to adapt the application of their knowledge to the regulations and cultural as well as institutional contexts of the countries in which they establish offices. Admittedly, they also seem, at least partially, to prefer foreign markets which share cultural and institutional similarities with their home countries. Nonetheless, the knowledge base itself must not be adapted to the external contexts. This opens up a far wider range of international business opportunities. Despite institutional barriers it is easier for them to open up national markets outside the EU. Engineering consulting firms established offices in regions and countries where law firms are barely or not at all present (see Fig. 1 and 2). This underscores the extent to which the internationalisation of engineering consulting firms is far less dependent on institutional contexts and this, in turn, enables a more widespread international presence.

\section{Influence of client relations}

Apart from the influence of the characteristics "nature of knowledge" and "institutional conditions/regulatory restrictions", MALHOTRA/ MORRIS (2009) have pointed out the differences in the client relationships of firms in both sectors, particularly in terms of the frequency of face-toface contact. The results of the cluster analysis reveal that this third factor is closely related to the distribution of locations within the target countries and the centrality of these locations.

Law firms are primarily concentrated at locations of high centrality (global cities) within foreign countries and they are usually limited to this location. Only in exceptional cases are decentralized locations selected, e.g. cities with EU institutions (Alicante). Such central locations are particularly advantageous for this type of service. Here they can find access to corporate headquarters, political institutions and potential customers in the respective country. The choice also reflects the fact that law firms are less distance sensitive because of the lower frequency of contacts between customer and supplier of services. In contrast, engineering service consulting companies can be found in both central cities and second tier cities and they often establish several branches in one country. This diversity points to two different patterns of customer relations depending on the specialisation of engineering services. First, companies located in central cities are often civil engineering firms who have chosen this location for customer acquisition and projectmanagement. From here, projects with temporary locations throughout the country are to be optimally controlled. Second, in contrast, the consulting services provided by industrial consulting companies require close and frequent contact with customers over longer periods. This seems to be the reason that these companies establish branches in non-central locations, often in the vicinity of manufacturing industries. Thus, the international locational patterns of KIBS firms partly mirror the firms' client structure and spatial organisation of their major client industries. 


\section{Conclusions}

With the help of a cluster analysis based on corporate data, we were able to explain some of the spatial characteristics of the internationalisation processes found in the two different knowledge intensive service sectors. It was revealed that heterogeneous characteristics, especially in terms of knowledge and client relationship, influence significantly the spatial outcome of economic processes. Accordingly, the notion of similarity, often implicitly assumed when discussing KIBS, has to be questioned. This conclusion brings with it the insight that some sectors of KIBS are not as global as the literature focusing on the world's leading business services companies might suggest (e.g. JONES 2005; FAULCONBRIDGE et al. 2008; FAULCONBRIDGE 2009). Rather, it appears that only a few European firms, especially those in legal services, act as global players. This observation hints at a further dimension of heterogeneity within sectors. The types of office networks resulting from the cluster analysis clearly revealed distinct differences within the sectors which seem to relate to type of subsector, size of company or country of origin.

Given this heterogeneity within and between sectors of KIBS, it is an open question as to how the differing organisational and spatial characteristics influence firm behaviour in international business environments. A crucial challenge for knowledge intensive service providers is to mediate between the different knowledge and institutional arrangements of different countries. A central question here is how the companies react in the local context in foreign markets and how the home market conditions, the experience in internationalisation, the companies' networks and the enterprise culture influence behaviour in foreign markets. Therefore, it is worth examining the influence of sector characteristics on strategies of expansion and forms of local adaption.

\section{Acknowledgement}

Research funding was provided by the Deutsche Forschungsgemeinschaft (German Research Foundation); project KU 1191/4-1, KU 884/20-1.

\section{Note}

1 At first, a principal component analysis was applied to orthogonalize and standardise the variables. Subsequently we used Ward's method as clustering method which minimizes the within-group variation and maximises the variation between groups. Afterwards, we applied a discriminant analysis to address a weakness of hierarchical cluster analysis - not being able to regroup single objects in the clustering process (BAHRENBERG et al. 2003, 278 ff.).

\section{References}

Asheim, B. T./ Ebersberger, B./ Herstad, S. J. (2010): MNCs between the local and the global. Knowledge bases, proximity and distributed knowledge networks. London. (DRUID, Paper submitted to the Summer Conference 2010 at Imperial College London Business School, 16-18 June, 2010).

ArAnDA, D.A. (2002): Relationship between operations strategy and size in engineering consulting firms. In: International Journal of Service Industry Management, (13)3, 263-285.

BADIRU, A. (Ed.)(2005): Handbook of industrial and systems engineering. Boca Raton, FL.

BAhrenberg, G./Giese, E./ NiPPER, J. (2003): Statistische Methoden in der Geographie 2. Multivariate Statistik. Stuttgart.

Bathelt, H./ Malmberg, A./ Maskell, P. (2004): Clusters and knowledge. Local buzz, global pipelines and the process of knowledge creation. In: Progress in $\mathrm{Hu}-$ man Geography, 28, 31-56.

Beaverstock, J.V./ Smith, H.G./ TAYlor, P.G. (1999): A roster of world cities. In: Cities, (16)6, 445-458.

BeAVERstock, J.V. (2004): 'Managing across borders'. Knowledge management and expatriation in professional service legal firms. In: Journal of Economic Geography, (4)2, 157-179.

BeugelsdiJK, S./ Frijns, B. (2010): A cultural explanation of the foreign bias in international asset allocation. In: Journal of Banking \& Finance, (34)9, 2121-2131.

Berry, H./ GuilléN, M.F./ Zhou, N. (2010): An institutional approach to cross-national distance. In: Journal of International Business Studies, (41)9, 1460-1480.

Bryson, J./ DANiels, P./ WARF, B. (2007): Service worlds. London, New York.

Chambers \& Partners: Europe guide. Internet: http:// www.chambersandpartners.com/Europe; 11/2010.

CIA (Central Intelligence Agency): The world factbook. Internet: https://www.cia.gov/library/publications/theworld-factbook, 04/2011.

Coe, N.M./ Dicken, P./ Hess, M. (2008): Global production networks. Realizing the potential. In: Journal of Economic Geography, 8, 271-295.

Coviello, N./ MARTIN, K. (1999): Internationalization of service SMEs. An integrated perspective from the engineering consulting sector. In: Journal of International Marketing, (7)4, 42-66.

Emory Law: Legal profiles. Internet: http://www.law. emory.edu/ifl/legal/, last access: 05/2012.

FAULCONBRIDGE, J.R. (2006): Stretching tacit knowledge beyond a local fix? Global spaces of learning in advertising professional service firms. In: Journal of Economic Geography, (6)4, 517-540. 
FAULCONBRIDGE, J.R. (2007): London's and New York's advertising and law clusters and their networks of learning. Relational analyses with a politics of scale? In: Urban Studies, (44)9, 1635-1656.

FAULCONBRIDGE, J.R. (2008): Negotiating cultures of work in transnational law firms. In: Journal of Economic Geography, (8), 497-517.

FAulconbridGe, J.R. (2009): The Regulation of design in global architecture firms. Embedding and emplacing buildings. In: Urban Studies, (46)12, 2537-2554.

Faulconbridge, J.R. /Beaverstock, J.V. /Muzio, D./ TAYLOR, P.J. (2008): Global law firms. Globalization and organizational spaces of cross-border legal work. In: Northwestern Journal of International Law and Business, (28)3, 455-488.

FAulconbridge, J.R./ Muzio, D. (2012): Professions in a globalising world. Towards a transnational sociology of the professions. In: International Sociology, (27)1, 136-152.

Fenton, E./ Pettigrew, A. (2000): Integrating a global professional services organization. The case of Ove Arup partnership. In: Pettigrew, A./ Fenton, E. (Eds.): The innovating organization. London, 47-81.

Ghemawat, P. (2001): Distance still matters. The hard reality of global expansion. In: Harvard Business Review, (79)8, 137-147.

GLÜCKLER, J. (2004): Reputationsnetze. Zur Internationalisierung von Unternehmensberatern. Eine relationale Theorie. Bielefeld.

GLÜCKLER, J. (2006): A relational assessment of international market entry in management consulting. In: Journal of Economic Geography, (6)3, 369-393.

GLÜCKLER, J./ ARMBRÜSTER, T. (2003): Bridging uncertainty in management consulting. The mechanisms of trust and networked reputation. In: Organization Studies, (24)2, 269-297.

HAas, H.-D./ NAumair, S.-M. (2006): Internationale Wirtschaft. Rahmenbedingungen, Akteure, räumliche Prozesse. München.

Hall, P.A./ Soskice, D. (2001): An introduction to varieties of capitalism. In: Hall, P.A./ Soskice, D. (Eds.): Varieties of capitalism. The institutional foundations of comparative advantages. Oxford, 1-68.

Halliday, T.C. (1985): Knowledge mandates. Collective influence by scientific, normative and syncretic professions. In: The British Journal of Sociology, (36)3, 421-447.

Henderson, J./ Dicken, P./ Hess, M./ Coe, N./ Yeung, H.W. (2002): Global production networks and the analysis of economic development. In: Review of International Political Economy, (9)3, 436-464.

Hess, M. (2004): 'Spatial' relationships? Towards a reconceptualization of embeddedness. In: Progress in Human Geography, (28)2, 165-186.

HG.org Legal Directories: Law firms by country and practice area. Internet: http://www.hg.org/countries. html, 11/2010.

Johanson, J./ VAHLNE, J. (1977): The internationalization process of the firm - a model of knowledge devel- opment and increasing foreign market commitments. In: Journal of International Business Studies, (8)1, 23-32.

JONES, A. (2005): Truly global corporations? Theorizing organizational globalization in advanced business services. In: Journal of Economic Geography, (5), 177200.

JONES, A. (2007): More than 'managing across borders? 'the complex role of face-to-face interaction in globalizing law firms. In: Journal of Economic Geography, (7), 223-246

JUVE (2011): Top 70 deutscher Kanzleien. Internet: http://www.juve.de/, 05/2011.

Kreitl, G./ OBERndorfer, W.J. (2004): Motives for acquisitions among engineering consulting firms. In: Construction Management and Economics, (22)7, 691-700.

Kujath, H.J./ Stein, A. (2009): Rekonfigurierung des Raumes in der Wissensgesellschaft. In: Raumforschung und Raumordnung, (67)5-6, 369-382.

KULKE, E. (2011): Internationalisierung des Einzelhandels - das Beispiel IKEA. In: Geographische Rundschau, (63)5, 12-19.

Law.com: The global 100 2010. The world's highest grossing law firms. Internet: http:/www.law.com/ jsp/tal/PubArticleTAL.jsp?id=1202472338838\&slretur $\mathrm{n}=1 \&$ hbxlogin=1, 07/2011.

The Lawyer: European 100. Link: http://www.centaur2. co.uk/emags/thelawyer/TL_Euro_100/, 11/2010.

The Lawyer: UK 200 revenue table 2010. Firms 1-100. Internet: http://www.thelawyer.com/directory/uk-200table-top-100/, 11/2010.

LøWENDAHL, B. (2005): Strategic management of professional service firms. Copenhagen.

Malhotra, N./ Morris, T. (2009): Heterogeneity in professional service firms. In: Journal of Management Studies, (46)6, 895-922.

Morgan, G./ QuACK, S. (2005): Institutional legacies and firm dynamics. The growth and internationalization of UK and German law firms. In: Organization Studies, 26, 1765-1785.

MatTes, J. (2012): Dimensions of proximity and knowledge bases. Innovation between spatial and non-spatial factors. In: Regional Studies, (46)8, 1085-1099.

Moschett, D. (2007): Institutionalisierung und Koordination von Auslandseinheiten. Analyse von Industrieund Dienstleistungsunternehmen. Wiesbaden.

NuHN, H. (2007): Globalisierung und Verkehr weltweit vernetzte Transportsysteme. In: Geographische Rundschau, (59)5, 4-12.

Ojanen, V./ SAlmi, P/ Torkkeli, M. (2008): Cross-border acquisitions in technical engineering sector. Motives, trends and effects in Finnish consultancies. In: International Journal of Management Science and Engineering Management, (3)2, 151-160.

Osiel, M.J. (1990): Lawyers as monopolists, aristocrats, and entrepreneurs. In: Harvard Law Review, (103)8, 2009-2066.

Pöllath, R./ SAenger, I. (2009): 200 Jahre Wirtschaftsanwälte in Deutschland. Baden-Baden. 
SEDLACEK, P. (2003): Dienstleistungen in Deutschland Hoffnung oder Enttäuschung des 21. Jahrhunderts? In: Geographie und Schule, (25)141, 12-18.

STD (2009): Sector review. The consulting engineering and architectural aroups. A Swedish and international survey. Stockholm.

Stahlecker, T./ Kulicke, M./ Jung, B. (2006): Die Internationalisierung von Dienstleistungen. Eine Analyse der aktuellen Entwicklungen und wichtiger Wettbewerber. Stuttgart. (ISI-Schriftenreihe Innovationspotentiale).

StRAMBACH, S. (2008): Knowledge-intensive business services (KIBS) as drivers of multi-level knowledge dy- namics. In: International Journal of Service and Technology Management, (10), 2-3-4, 152-174.

Strambach, S./ Storz, C. (2008): Pfadabhängigkeit und Pfadplastizität von Innovationssystemen. Die deutsche und japanische Softwareindustrie. In: Vierteljahrshefte zur Wirtschaftsforschung, 2, 142- 161.

United Nations Statistic Division (2010): Composition of macro geographical (continental) regions, geographical sub-regions, and selected economic and other groupings. Internet: http://unstats.un.org/unsd/methods/ m49/m49regin.htm, 06/2011.

WINCH, G. M. (2008): Internationalisation strategies in business-to-business services. The case of architectural practice. The Service Industries Journal, (28)1, 1-13. 